\title{
Fiscal federalism and socio-economic asymmetry
}

He who controls the economy controls the polity. But who does control the purse strings in Russia, and how are federal funds distributed across the federation? To what degree have federal policies ameliorated the high levels of socio-economic asymmetry inherited from the USSR? To answer these questions we need to examine fiscal federalism taking into account both the formal structural aspects of the system and the more hidden informal practices.

\section{Fiscal federalism}

As Bradshaw and Hanson note, 'fiscal federalism brings together an analysis of the workings of the federal system in Russia with an assessment of the logic underlying the redistribution of federal tax revenues between regions'. ${ }^{1}$ In addition to the formal income and expenditure flows between federal and subnational budgets which are distributed through the tax system, it is important to note that there are a wide range of other forms of fiscal transfers: subventions, net mutual payments, credits, social welfare programmes, and off-budget funds.

Ideally, fiscal federalism, it is argued, 'should promote territorial justice, economic efficiency, and political stability'.2 According to Hanson et al., fiscal federalism requires that: (1) the responsibilities of each level of government should be clearly delineated; (2) sub-national governments should have the means for primary control over economic matters within their jurisdiction; (3) the budgets of sub-national governments should be substantially independent of those at higher levels; (4) transfers between levels should be based on stable, transparent, public-domain formulae. ${ }^{3}$ As we shall see Russia is still very far away from implementing these principles. 


\section{Fiscal centralisation or decentralisation}

Two of the most commonly employed measures of fiscal decentralisation, 'are the share of the subnational budgets in consolidated revenue and expenditures, and the degree to which subnational budgets consist of revenue raised on their territories as opposed to transfers'. ${ }^{4}$ And by both of these (aggregate) measures the Russian system especially over the period 1993-98 was 'rather decentralised'. ${ }^{5}$ Thus, as table 5.1 clearly demonstrates, in 1992 the balance of funds between the federal and subnational budgets was a ratio of 56.0/44.0 per cent in favour of the centre. However, over the period 1993-99 there was a steady increase in the share of revenues allocated to the regional budgets, so that by 1998 the balance of revenues was the reverse of that found in 1992, 44.0/56.0 per cent in favour of the regions. Nevertheless, by 2001 President Putin had shifted the balance back in favour of the centre (55.0/45.0 per cent). ${ }^{6}$

Turning to an examination of the share of federal transfers in subnational budgets these made up approximately 15 per cent in Russia in 1999 compared with 30 per cent in India, China and Mexico, and 25 per cent in Brazil.

However, as Lavrov et al., note, when we measure levels of decentralisation according to formal levels of 'subnational autonomy' we find that the Russian system is highly centralised. Thus, compared to federations such as Canada, Switzerland and the US, where subnational governments have a great deal of fiscal autonomy, in Russia the vast majority of decisions concerning the income and expenditure of subnational budgets are decided by the Federal Government in Moscow. Indeed, in the Russian Federation 'just 15 per cent of regional revenue derives from taxes over which the regional authorities have any sort of real decision making authority, and even these taxes are usually rigidly regulated from above or subject to federal spending ceilings' ${ }^{8}$

Moreover, according to changes made to the tax code that became operational in January 2001 the Federal Government has increased its

Table 5.1 Share of the income of federal and territorial (subnational) budgets (\%) in total state revenue, 1992-2001

\begin{tabular}{lcccccccccc}
\hline & 1992 & 1993 & 1994 & 1995 & 1996 & $1997^{a}$ & 1998 & 1999 & 2000 & 2001 \\
\hline Federal budgets & 56.0 & 49.0 & 48.0 & 54.0 & 49.0 & 47.0 & 44.0 & 51.0 & 52.0 & 55.0 \\
Territorial budgets & 44.0 & 50.0 & 52.0 & 46.0 & 51.0 & 53.2 & 56.0 & 49.0 & 48.0 & 45.0 \\
\hline
\end{tabular}

Source: Data for 1992-97, Yu. N. Gladkii and A. I. Chistobaev, Osnovy Regional'noi Politiki (St Petersburg: Izdatel'stvo Mikhailova V.A., 1998), p. 430; for 2000, EWI Russian Regional Report 5:30 (August 2, 2000); for 2001, EWI RRR, 6:20 (May 30, 2001), pp. 4-5.

Note: ${ }^{a}$ January-June 1997. 
control over regional finances even further. Thus, for example, the centre now controls 100 per cent of the value-added tax whereas previously the regions controlled 15 per cent of it. The regions have also been left with a smaller percentage of turnover tax to finance housing and roads. Responding to these developments, Belgorod Governor Yevgenii Savchenko declared that the new tax regime would lead to the 'formation of a unitary state in which all regions will be dependent on the centre'. 9 And 'Moscow Mayor Yurii Luzhkov warned that the Federal Government would now control 65 per cent of the country's revenue, leaving only 35 per cent for the regions'. ${ }^{10}$ As we shall discuss below, the vast majority of regions have had to rely on additional fiscal transfers from the federal budget to meet their expenditure obligations. However, the creation of a single 'Fund for the Financial Support of Subjects of the Federation' in 1994 has been a positive factor in channelling such extra resources to the most needy regions. ${ }^{11}$

In discussing fiscal federalism we need to make a distinction between 'structure' and 'process'. For whilst in formal terms the fiscal system is highly centralised, in practice it operates with a high degree of regional autonomy operating behind the scenes. As the 2000 OECD Report concludes, 'Recent years have witnessed a striking and growing contrast between a formal highly-centralised fiscal federalist system and actual practice, under which a large degree of financial authority is exercised at the subnational level through informal channels'. ${ }^{12}$

Non-budget' (or 'off-budget') funds are one such informal channel through which the regions are able to exercise a considerable degree of local autonomy. These funds include pensions and roads funds, income from export privileges, and hard currency allocations. As Makushkin notes, almost 50 per cent of these funds are allocated to finance social services. But, 'unlike formal budgetary issues, the spending part of these non-budgetary funds is not controlled by the federal treasury'. This opens the way for bureaucratic manipulation of these financial sources and provides grounds for corruption. ${ }^{13}$ 'Money surrogates, particularly debt offsets, have been used as primary tools for the conduct of relatively independent fiscal policies at the subnational level'. These include the use of 'barter chains', 'creative book keeping' and 'individualised tax treatment'. Moreover, regional administrations will often have very cosy relations with the financial institutions in their territories, including direct participation in their capital, indirect participation through affiliated companies, control of utilities, control of various inspections empowered to administer penalties and fines, close ties with the courts and federal anti-trust or tax bodies, licensing, and the police. ${ }^{14}$ As we noted in chapter 3 regional governors have also been able to capture control over the appointment of federal representatives including those from the Inspectorate of Taxes. 
Turning to an examination of the expenditure side of budget relations, the OECD in its Economic Survey of Russia in 2000 noted that, 'ambiguity in expenditure assignments has plagued the development of fiscal federalist relations in Russia' ${ }^{15}$ In particular there has been a lack of clarity over those areas, such as education, health and social policy, which come under the joint jurisdiction of the regions and the federal government. In most cases the vast majority of such expenditures have been delegated to the subnational levels in the form of unfunded federal mandates (amounting to 600 billion roubles in 2001 or 8 per cent of the country's GDP) which most regional governments are too poor to implement. As a result, almost all regions suffer from chronic budget deficits. Thus, for example, in 1997 only Moscow city and the Nenets AO had balanced budgets. ${ }^{16}$

As was the case in the communist era, local administrations have also relied on local deals with the major enterprises situated on their territories for the provision of social services and maintenance of the local infrastructure. ${ }^{17}$ In return, these enterprises can expect to be rewarded with special 'tax privileges, debt restructuring, and protection from bankruptcy or competition'. ${ }^{18}$ Thus for example, Chelyabinsk Governor, Petr Sumin announced that he was granting political protection from possible bankruptcy to the 200 companies that were most important to the region's economy. ${ }^{19}$ In many cases regional administrations will also own shares in local enterprises, and will have their own authorised commercial banks to conduct their financial affairs. Sverdlovsk Governor Eduard Rossel issued a decree preventing shareholders in key oblast companies from removing directors without first gaining his approval and he needled his way into bankruptcy proceedings in the region by establishing an oblast controlled management company. Privatisation of industry has also increased the opportunity for regional leaders and enterprise directors to engage in such bilateral deals, and it has put a great deal of regional economic policy out of the hands of the federal government in Moscow.

\section{Economic and social asymmetry}

There are vast differences across the Federation both in the economic status of federal subjects and the welfare provisions of their citizens. And despite the official policy, pursued for many years, of evening out the level of social, economic and cultural developments in the various regions, there are very great differences among them in terms of the level of production and consumption. According to Hanson, 'the 89 Russian provinces probably differ more widely in development level than the member states of the European Union' ${ }^{20}$ Indeed, the territory of the Russian Federation presents the whole spectrum of development from 
the 'agrarian' stage to the 'industrial' stage. ${ }^{21}$ And economic strength leads to differentials in the political powers of regional elites. However, as we have shown in chapter 3, bilateral treaties have intensified the existing levels of socio-economic asymmetry in the Federation creating tensions both horizontally between members of the federation and vertically between subjects and the federal government.

Elites in rich and financially independent regions, such as the so called 'donor regions' will have far greater bargaining powers with the federal authorities than elites from regions which are economically dependent on the centre. As we noted in chapter 4 the economic status of federal subjects will have an important impact on their sovereignty and secessionist claims. Those subjects which are mired in poverty, and depend on federal handouts are hardly likely to pose any real ethnic or separatist challenge to Moscow.

\section{Industrial production and gross regional product}

There are tremendous variations in the volume of industrial production which ranged from a high of 228.929 million roubles in Tyumen Oblast to just 13 million in the tiny Yevenk AO, in 1998. In 1999 gross regional product varied from 362.5 billion roubles in Moscow to 1.1 billion roubles in Ingushetiya (table 5.2).

\section{Foreign investment and exports}

In 1999 the export industry in Moscow was worth 11.3 billion dollars whereas in each of the following regions the total value of exports was less than 10 million dollars; Tyva, Altai, Adygeya, Karachaevo-Cherkessiya, Kalmykiya, Komi-Permyak, Agin-Buryatiya and Ust'-Ordina Buryatiya AOs and the Yevreiskii Autonomous Oblast. ${ }^{22}$

There are also sharp variations in the levels of foreign investment, with the top ten regions attracting 80.4 per cent of all such investments in 1995 and 75.5 per cent in 1999. In 1995 nearly half of all foreign investments were directed to Moscow city (46.9 per cent), and in 1999 over a quarter (27.8 per cent), see table 5.3.

\section{Tax contributions to the federal budget}

These sharp variations in the level of economic development have led to a situation whereby just two-thirds of all taxes paid to the federal budget come from just 10 of Russia's 89 regions. And Moscow's contributions in 1998 and 1999 made up approximately one-third of the total tax revenues going to the federal budget (see table 5.4). ${ }^{23}$ 
Table 5.2 Top ten and bottom ten regions of Russia according to volume of gross regional product (GRP) in 1998 and industrial production (IP) in 1999

\begin{tabular}{|c|c|c|c|}
\hline Region & $\begin{array}{c}\text { GRP } \\
\text { (billion roubles) }\end{array}$ & Region & $\begin{array}{c}I P \\
\text { (million roubles) }\end{array}$ \\
\hline Top ten & & Top ten & \\
\hline Moscow city & 362.5 & Tyumen Oblast & 228,929 \\
\hline Tyumen Oblast & 201.2 & Khanty-Mansi AO & 176,787 \\
\hline Moscow Oblast & 100.6 & Moscow city & 175,054 \\
\hline St.Petersburg & 89.8 & Krasnoyarsk Krai & 124,498 \\
\hline Sverdlovsk Oblast & 80.7 & Sverdlovsk Oblast & 114,714 \\
\hline Samara Oblast & 72.7 & Samara Oblast & 108,102 \\
\hline Krasnoyarsk krai & 71.6 & St.Petersburg & 104,671 \\
\hline Tatarstan & 67.7 & Tatarstan & 100,534 \\
\hline Bashkortostan & 64.2 & Chelyabinsk Oblast & 91,134 \\
\hline Perm & 55.6 & Bashkortostan & 89,872 \\
\hline Bottom ten & & Bottom ten & \\
\hline Kabardino-Balkariya & 6.4 & Kalmykiya & 910 \\
\hline North Osetiya-Alaniya & 4.1 & Chukotka & 868 \\
\hline Adygeya & 3.4 & Buryatiya & 609 \\
\hline Karachaevo-Cherkesiya & 2.9 & Ingushetiya & 406 \\
\hline Chukotka & 2.6 & Permyak & 249 \\
\hline Evreiskii & 1.8 & Altai Republic & 227 \\
\hline Tyva & 1.8 & Chita Oblast & 117 \\
\hline Kalmykiya & 1.7 & Taimyr & 66.8 \\
\hline Altai Republic & 1.6 & Agin-Yevenk & 60.6 \\
\hline Ingushetiya Republic & 1.1 & Buryatiya & 13.0 \\
\hline
\end{tabular}

Source: Rossiya v Tsifrakh (Moscow: Goskomstat, 2000), pp. 34-41.

\section{Variations in the standard of living and social conditions}

These sharp variations in economic development are also reflected in wide regional variations in the standard of living of the Russian population. Thus, for example, in 1999 monthly expenditure per capita in the resource-rich Yamalo-Nenets $\mathrm{AO}$ was twice the national average and seventeen times that of poverty stricken Ingushetiya. Average income per capita in the city of Moscow was four times the national average and fifteen times greater than in Ingushetiya (see table 5.5). In comparison, variations in the average income per capita in the German Lander vary by a factor no greater than 1.5. However, it is important to remember that such inequalities in Russia were the result of a sharp and prolonged 
Table 5.3 Ten largest regions according to their share of total volume of foreign investment in 1995 and 1999 (\%)

\begin{tabular}{lrlr}
\hline & 1995 & & 1999 \\
\hline Moscow & 46.9 & Moscow & 27.8 \\
Moscow Oblast & 7.4 & Sakhalin Oblast & 10.7 \\
Tatarstan & 5.8 & Omsk Oblast & 9.3 \\
St Petersburg & 5.6 & St Petersburg & 7.3 \\
Tyumen Oblast & 3.7 & Krasnodar Krai & 5.3 \\
Samara Oblast & 2.5 & Moscow Oblast & 4.6 \\
Tver Oblast & 2.4 & Nenets AO & 3.6 \\
Nizhegorod Oblast & 2.2 & Leningrad Oblast & 3.0 \\
Novosibirsk Oblast & 2.1 & Krasnoyarsk Krai & 2.1 \\
Sakhalin Oblast & 1.8 & Sverdlovsk Oblast & 1.8 \\
Total & & & 75.5 \\
\hline
\end{tabular}

Source: Leonid Vardomskii, 'Vneshneekonomicheskie svyazi regionov', in Russian Regions in 1999: An Annual Supplement to Russia's Political Almanac (Moscow: Carnegie Centre, 2000), p. 114 .

economic decline in the overall growth of the Russian economy. As Hanson and Bradshaw point out Russian GDP fell by 47 per cent over the ten-year period 1989-99. ${ }^{24}$

The average monthly wage in the oil rich Khanty-Mansi AO in 2000 was four times the national average, and 10.4 times higher than in the Republic of Dagestan. ${ }^{25}$ In 1999 the average level of unemployment in the Russian Federation was 13.4 per cent but there were wide variations across the country ranging from 5.6 per cent in Moscow City to 31.2 per cent in Dagestan, 33.4 per cent in North Osetiya-Alaniya, and 51.8 per cent in refugee flooded Ingushetiya. ${ }^{26}$ There are also significant variations in the level of poverty across the Federation. In 1995 there were 51 subjects of the Federation where a quarter of the population or higher were living below the officially recognised subsistence level, including 5 subjects where the figure was over 50 per cent, Kurgan (50 per cent), Buryatiya (55), Kalmykiya (60), Chita (67), and Tyva (73 per cent). ${ }^{27}$ In 1999 in the aftermath of the August 1998 economic crises there was a substantial increase in the number of subjects where poverty levels exceeded 25 per cent (79 regions) and where over half the population were living below the poverty line (29 regions). ${ }^{28}$ Of these, Agin-Buryatiya $\mathrm{AO}$ and Ingushetiya had staggeringly high levels of 96.8 and 95.1 per cent respectively; Ust'-Ordin Buryatiya AO (89.4 per cent), Chita Oblast (88.8 per cent) and Tyva (78.6 per cent). In contrast, at the other end of the scale, Yamalo-Nenets AO had a poverty level of 13.3 per cent, Khanty-Mansi 
Table 5.4 Concentration of tax contributions to the federal budget, 1996-98

\begin{tabular}{lcccc}
\hline & 1996 & 1997 & 1998 & 1999 \\
\hline $\begin{array}{c}\text { Share of taxes of federal budget } \\
\text { collected in Moscow }\end{array}$ & 26.0 & 30.9 & 36.1 & 32.71 \\
$\begin{array}{c}\text { Share of taxes of federal budget } \\
\text { collected in first 5 regions }\end{array}$ & 47.3 & 52.7 & 55.1 & 51.53 \\
$\begin{array}{c}\text { Share of taxes of federal budget } \\
\text { collected in first 10 regions }\end{array}$ & 59.6 & 64.3 & 65.4 & 62.74 \\
\hline
\end{tabular}

Source: Figures for 1996-98, O.V. Kuznetsova, 'Territorial'naya struktura nalogovovo potentsiala', in A. M. Lavrov (ed.), Federal'nyi Byudzhet i Regiony: Opyt Analiza Finansovykh Potokov (Moscow: Instityt Vostok Zapad, MAKS Press, 1999), p. 64; figures for 1999, Olga Kuznetsova, 'Regional'nye Byudgety', in Russia's Regions in 1999: An Annual Supplement to Russia's Political Almanac (Moscow: Carnegie Centre, 2000), p. 77.

Note: ${ }^{a}$ The first ten regions in 1999 were: Moscow (32.71), Khanty-Mansi AO (6.45), St Petersburg (4.54), Moscow Oblast (4.33), Samara Oblast (3.50), Yamalo-Nenets A0 (2.85), Krasnodar Krai (2.25), Krasnoyarsk Krai (2.07), Perm Oblast (2.05), and Sverdlovsk Oblast (1.99).

Table 5.5 Regional variations in per capita income and expenditure, 1999

\begin{tabular}{|c|c|c|c|}
\hline & $\begin{array}{l}\text { Monthly income } \\
\text { (thousand roubles) }\end{array}$ & & $\begin{array}{c}\text { Monthly } \\
\text { expenditure } \\
\text { (thousand roubles) }\end{array}$ \\
\hline Moscow City & 6,002 & Yamalo-Nenets AO & 3,011 \\
\hline Yamalo-Nenets AO & 5,297 & Magadan Oblast & 2,407 \\
\hline Khanty-Mansi AO & 4,329 & Samara Oblast & 2,352 \\
\hline Tyumen Oblast & 3,371 & Tyumen Oblast & 2,216 \\
\hline Sakha Republic & 2,797 & Kamchatka Oblast & 2,052 \\
\hline Ingushetiya & 390 & Ingushetiya & 181 \\
\hline
\end{tabular}

Source: Rossiya v Tsifrakh (Moscow: Goskomstat, 2000), pp. 34-43.

AO (15.6 per cent), Tyumen Oblast (17.8 per cent), Murmansk (19.8 per cent), and Moscow city (23.3 per cent). ${ }^{29}$

In an excellent study of regional poverty which Smirnov conducted in 1997 each of Russia's regions was ranked according to seven key socioeconomic variables: ${ }^{30}$ (1) growth of the population in 1996 per 1000 inhabitants; (2) the balance of immigration/emigration in 1996 per 10,000 inhabitants; (3) level of unemployment as a percentage of economically active members of the population in 1997; (4) intensity of the labour market in 1997 calculated as the number of unemployed/to number of 
Table 5.6 Measuring poverty in Russia's regions, 1996-97

\begin{tabular}{lclc}
\hline $\begin{array}{l}1 \text { Regions with favourable } \\
\text { social conditions }\end{array}$ & $\begin{array}{c}\text { Average } \\
\text { rank }\end{array}$ & $\begin{array}{l}\text { 2 Regions with moderate } \\
\text { social conditions }\end{array}$ & $\begin{array}{c}\text { Average } \\
\text { rank }\end{array}$ \\
\hline Belgorod Oblast & 16.3 & Voronezh Oblast & 34.1 \\
Lipetsk Oblast & 17.4 & Ul'yanov Oblast & 34.3 \\
Moscow City & 19.4 & Sverdlovsk Oblast & 34.7 \\
Rep. Sakha (Yakutiya) & 19.7 & Nizhegorod Oblast & 35.0 \\
Orenburg Oblast & 20.1 & Novosibirsk Oblast & 35.7 \\
Rep. Tatarstan & 20.7 & Omsk Oblast & 35.9 \\
Stavropol' Krai & 20.9 & Astrakhan Oblast & 36.1 \\
Rep. Bashkortostan & 22.9 & Yevenk AO & 38.0 \\
Krasnoyarsk Krai & 23.3 & Kaluga Oblast & 38.1 \\
Rostov Oblast & 23.7 & Kamchatka Oblast & 39.4 \\
Yamalo-Nenets AO & 24.0 & Krasnoyarsk Krai & 39.4 \\
Khanty-Mansi AO & 26.2 & Volgograd Oblast & 39.9 \\
Tyumen Oblast & 26.3 & Tul'a Oblast & 39.9 \\
Smolensk Oblast & 27.4 & Tver Oblast & 40.0 \\
Vogograd Oblast & 27.9 & Magadan Oblast & 40.9 \\
Orel Oblast & 28.7 & Ryazan Oblast & 40.9 \\
St Petersburg & 28.9 & Kaliningrad Oblast & 41.4 \\
Kursk Oblast & 29.0 & Rep. Komi & 42.0 \\
Samara Oblast & 29.3 & Irkutsk Oblast & 42.6 \\
Moscow Oblast & 30.1 & Rep. Khakasiya & 43.7 \\
Kemerovo Oblast & 33.6 & Rep. Altai & 44.1 \\
Chelyabinsk Oblast & 33.7 & Amur Oblast & 44.3 \\
\hline
\end{tabular}

Source: S. N. Smirnov, Regional'nye Aspekty Sotsial'noi Politiki (Moscow: Gelios, 1999), pp. 63-4.

vacancies; (5) average length of time workers had been unemployed on December 31, 1996; (6) the ratio of average wages and payments from the Federal Social Fund to the minimum subsistence level of the able bodied population in December 1996; (7) housing provision in 1996, calculated as number of inhabitants per square metre.

Table 5.6 shows each region's average rank for all seven factors. The table is divided into four groups according to the aggregate rank of each region: (1) regions with relatively favourable social conditions, (2) regions with moderate conditions, (3) regions with unfavourable conditions, and finally, (4) regions in crises. Smirnov found that 44 of Russia's 89 regions were either regions in crises (22 regions) or regions with unfavourable social conditions (22 regions). And the gap between the most favourable region, Belgorod Oblast with an overall rank of 16.3, and the least favourable region, Ivanovo Oblast with a rank of 73.4, varied by a factor of 4.5 . 


\begin{tabular}{lclc}
\hline $\begin{array}{l}\text { 3 Regions with unfavourable } \\
\text { social conditions }\end{array}$ & $\begin{array}{c}\text { Average } \\
\text { rank }\end{array}$ & 4 Crises regions & $\begin{array}{c}\text { Average } \\
\text { rank }\end{array}$ \\
\hline Rep. Buryatiya & 44.4 & Sakhalin Oblast & 55.4 \\
Tomsk Oblast & 45.0 & Rep. Tyva & 55.9 \\
Saratov Oblast & 45.7 & Tambov Oblast & 57.0 \\
Ust'-Orda Buryat AO & 46.5 & Bryansk Oblast & 58.7 \\
Leningrad Oblast & 46.9 & Nenetskii AO & 58.8 \\
Novgorod Oblast & 47.3 & Rep Ingushetiya & 59.7 \\
Rep Kabardino-Balkariya & 47.9 & Yaroslavskaya Oblast & 59.9 \\
Khabarovsk Krai & 48.3 & Rep. Dagestan & 60.4 \\
Rep Karachaevo-Cherkesiya & 48.7 & Aginskii-Buryat AO & 60.5 \\
Taimyr AO & 49.3 & Rep. Kalmykiya & 60.6 \\
Yevreiskaya AOB & 49.5 & Rep. Udmurtskaya & 60.6 \\
Altai Krai. & 49.7 & Vladimir Oblast & 60.9 \\
Primorski Krai & 50.6 & Kurgan Oblast & 61.0 \\
Perm Oblast & 51.6 & Chita Oblast & 62.0 \\
Rep. North Osetiya-Alaniya & 52.0 & Pskov Oblast & 63.0 \\
Rep. Chuvashkaya & 52.1 & Kirov Oblast & 63.1 \\
Rep. Adygeya & 52.1 & Penza Oblast & 63.3 \\
Rep. Marii El & 53.1 & Arkhangelskaya Oblast & 64.9 \\
Rep. Kareliya & 53.1 & Komi-Perm Oblast & 65.2 \\
Chukotskii AO & 54.0 & Rep. Mordoviya & 65.3 \\
Kostroma Oblast & 54.1 & Koryakskii AO & 66.8 \\
Murmansk Oblast & 54.3 & Ivanovo Oblast & 73.4 \\
\hline
\end{tabular}

\section{Variations in taxes maintained}

There are also vast differences in the percentage of local taxes which regions are permitted to maintain for their own expenditures. Special tax concessions and increased federal subsidies have been a common occurrence in Russia and were also a central feature of many of the special agreements attached to bilateral agreements. Thus as table 5.7 demonstrates whilst the top ten regions in Russia were able to maintain between 74 and 82 per cent of the local taxes collected in their regions in 1996, those regions in the bottom ten were permitted to keep only between 9 and 54 per cent.

\section{Federal transfers}

There are also major variations in the degree to which federal subjects are dependent on federal subsidies and transfers. The number of regions 
Table 5.7 \% of local taxes maintained by subjects of the Federation, 1996

\begin{tabular}{lllr}
\hline Top ten regions & $\%$ & Bottom ten regions & $\%$ \\
\hline Vologda Oblast & 74 & Ingushetiya Republic & 9 \\
Komi-Permyak AO & 74 & Kalmykiya Republic & 41 \\
Ust'-Orda Buryat AO & 74 & Moscow City & 42 \\
Koryak AO & 75 & Khanty-Mansi AO & 43 \\
Novosibirsk Oblast & 76 & Yaroslavl' Oblast & 49 \\
Komi Republic & 76 & Omsk Oblast & 51 \\
Chukotka AO & 79 & Moscow Oblast & 52 \\
Khakasiya Republic & 80 & Orel Oblast & 53 \\
Yevenk AO & 82 & Samara Oblast & 53 \\
Aginsk-Buryat AO Okrug & 82 & Bryansk Oblast & 54 \\
\hline
\end{tabular}

Source: A. M. Laverov (ed.), Rossiiskie Regiony Posle Vyborov-96 (Moscow: Yuridicheskaya Literatura, 1997).

receiving such financial transfers has steadily increased from 39 in 1994; 66 in 1995; 75 in 1996; 81 in 1997; to 76 in both 1998 and 1999. However, as can be seen from table 5.9 the levels of such transfers have varied from $1-90$ per cent. $^{31}$

Lavrov divides the regions into five categories depending on the level of federal transfers in their budgets; in non-subsidised regions, money coming from federal sources accounts for less than 5 per cent of budget revenues. Slightly subsidised regions are those in which, federal assistance of all types accounted for less than 10 per cent of the budget. For subsidised regions, the federal share is $10-20$ per cent; for moderately subsidised areas, 20-50 per cent, and for heavily subsidised ones, more than 50 per cent. ${ }^{32}$ Table 5.8 shows major variations in the percentage of federal transfers in the total income of two highly divergent groups of federal subjects over the period 1994-96. For example, in 1994 as much as 91.9 per cent of Dagestan's income came from federal transfers whereas in Bashkortostan the figure was only 2.6 per cent. In 1996, 79.3 per cent of Ingushetiya's income came from such subsidies, whilst for Lipetsk Oblast the figure was only 1.2 per cent. And table 5.9 shows that in 1999 wide variations in the amount of federal transfers still persisted. Thus for example, such transfers comprised between 60 and 80 per cent in the Yevreiskaya Autonomous Oblast; the Agin-Buryatiya, Komi-Permyak, Koryak, and Yevenk AOs, and the republics of Dagestan, Tyva and Kabardino-Balkariya. Whilst in the Ust'-Orda Buryatiya $\mathrm{AO}$ and the Republic of Ingushetiya such transfers were even higher, comprising between 80 and 90 per cent. On the other hand, thirteen regions received no federal transfers: the cities of St Petersburg and Moscow; Moscow, 
Table 5.8 Federal transfers as \% of total income in twelve selected regions, 1994-96

\begin{tabular}{lrrr}
\hline Regions & 1994 & 1995 & 1996 \\
\hline Group A & & & \\
Aga-Buryat AO & 83.3 & 69.4 & 68.6 \\
Altai Republic & 85.0 & 74.7 & 61.9 \\
Dagestan Republic & 91.9 & 64.4 & 55.5 \\
Ingushetiya Republic & 91.3 & 77.0 & 79.3 \\
Koryak AO & 81.6 & 81.6 & 68.1 \\
Tyva Republic & 86.0 & 78.7 & 68.5 \\
& & & \\
Group B & & & \\
Bashkortostan Republic & 2.6 & 0.2 & 2.8 \\
Yamalo-Nenyets AO & 3.7 & 1.2 & 2.0 \\
Lipetsk Oblast & 12.7 & 1.1 & 1.2 \\
Samara Oblast & 7.7 & 1.2 & 1.4 \\
Sverdlovsk Oblast & 3.4 & 2.1 & 1.9 \\
Rep. Tatarstan & 7.7 & 0.9 & 2.2 \\
\hline
\end{tabular}

Source: A. M. Laverov (ed.), Rossiiskie Regiony Posle Vyborov96 (Moskva: Yuridicheskaya Literatura, 1997).

Lipetsk, Samara, Perm, and Sverdlovsk oblasts; Khanty-Mansi and Yamalo-Nenets autonomous okrugs; the republics of Komi, Tatarstan, and Bashkortostan, and Krasnoyarsk Krai; and in a further 17 regions such transfers made up less than 10 per cent.

\section{Donor and recipient regions}

For Lavrov the donor regions are equivalent to the non-subsidised regions which we describe above, i.e. those regions where federal transfers account for less than 5 per cent of budget revenues. In 1999, there were thirteen donors (St Petersburg and Moscow cities; Moscow, Irkutsk, Lipetsk, Samara, Perm and Sverdlovsk oblasts; republics of Bashkortostan and Tatarstan; Khanty-Mansi and Yamal-Nenets AOs, and Krasnoyarsk Krai). ${ }^{33}$

On the other hand, recipient regions, according to Kuznetsova, are those regions where the volume of taxes paid into the federal budget is less than the volume of financial assistance paid to the regions from the federal budget. In 1999 there were twenty-four recipient regions. The vast majority of which were to be found in the republics of the Northern Caucuses and the regions of Eastern Siberia and the Far East. Thus, for 
Table 5.9 Typology of regions of Russia according to the share of federal budget transfers as a \% of total budget income, 1999

Share of federal
transfers in income
of budget

None

Up to 10

From 10-20

From 20-30

From 30-40

From 40-60

From 60-80

From 80-90
Regions (ranked according to the share of transfers coming from federal budget)
Cities of St Petersburg and Moscow; Moscow, Lipetsk, Samara, Perm, and Sverdlovsk oblasts; Khanty-Mansi and Yamalo-Nenets autonomous okrugs; republics of Komi, Tatarstan, and Bashkortostan; Krasnoyarsk Krai.

Vologda, Chelyabinsk, Nizhegorod, Yaroslavl', Leningrad, Belgorod, Irkutsk, Orenburg, Novosibirsk, Tiumen (without okrugs), Tula, Murmansk, Volgograd, Tomsk, Omsk, $\mathrm{Ul}^{\prime}$ yanovsk, Smolensk oblasts.

Kursk oblast; Udmurt republic; Tver oblast, Krasnodar krai; Kirov, Kaliningrad, Saratov, Nenets AO; republic of Khakasiya; Kemerovo oblast; Republic of Kalmykiya; Novgorod, Voronezh, Vladimir, Arkhangelsk oblasts; Stavropol' Krai; Astrakhan oblast; Republic of Kareliya; Rostov oblast.

Ryazan, Kaluga oblasts; Republic of Sakha (Yakutiya); Chuvash Republic; Kostroma oblast; Khabarovsk Krai; Bryansk, Magadan, Penza, Tambov oblasts; Primorsk Krai; Taimyr autonomous okrug; Kurgan, Sakhalin oblasts.

Ivanovo, Amur, Orel, Chita, Pskov, Kamchatka oblasts; Republic of Mordoviya.

Republics of Marii El, Buryatiya; Altai Krai; Republics of Altai and Adygeya; Karachaevo-Cherkessiya republic; Chutkotka AO; Republic of North Osetiya (Alaniya).

Evreiskaya autonomous oblast; Komi-Permyak, Koryak, and Yevenk AOs; Republic of Dagestan; Agin-Buryatiya $\mathrm{AO}$; republics of Tyva and Kabardino-Balkariya.

Ust'-Ordin Buryatiya AO; Republic of Ingushetiya.

Source: L. I. Sergeev, Gosudarstvennye I Territorial'nye Finansy (Kaliningrad: Yantarnyi skaz, 2000), p. 142.

example, the volume of financial assistance from the federal budget exceeded tax payments to the federal income by almost 13 times in the Yevenk AO, approximately 10 times in Dagestan, and the Chukotka AO, from 8-9 times in Tyva and Ust-Ordin Buryatiya AO, and 4.7 times in the Yevreiskaya autonomous oblast (AOB). ${ }^{34}$ 


\section{Political criteria for budget transfers and privileges}

Until now the centre has been quite successful in its use of economic levers to dampen down nationalist demands. The centre has also been adroit at playing the game of divide and rule and capitalising on the major economic differences between the regions by playing one region off against another. As Lavrov notes, recipient regions will 'be the most staunch supporters of preserving or even increasing centralization of tax revenues', so as to benefit from tax redistribution. Donor regions on the other hand are interested in reducing the territorial redistribution of budget resources; decentralising control of budget expenditures, and, especially, revenues; acquiring special budget status; creating their own tax services ... [and] removing their financial agencies from the control of the Russian Ministry of Finance. ${ }^{35}$

Yeltsin also sought to buy support from recalcitrant regional elites. As Tolz and Busygina note, despite the attempts undertaken since 1994 to rationalize the system of federal aid by introducing a publicised formula favouring needier regions, the system of redistribution of benefits and support apparently continues to be dependent on the political preferences of Moscow and the personal relations of governors with representatives of the federal executive. ${ }^{36}$

Political criteria have dominated in the distribution of budget funds and other federal transfers in both the Yeltsin and Putin regimes. Yeltsin as we have seen gave special privileges to forty-six subjects of the federation by signing bilateral treaties with them, and he has frequently used his control over budgetary transfers to quell ethnic unrest, dampen republican bids for political autonomy, purchase electoral votes, and neutralise potential regional opposition movements.

Paradoxically it is the 'oppositionist regions' and not the 'loyal subjects' which have fared best in such budget transfers. Whilst resource-rich Tatarstan, Bashkortostan and Sakha have been rewarded with special deals, and ethnically troubled Kabardino-Balkariya, North OsetiyaAlaniya and Chuvashiya were likewise privileged; impoverished but trouble-free subjects such as Tyva and Koryakiya have so far been left out. In other words loyal but poor republics and regions have been penalised whilst rich or potentially troublesome subjects have been rewarded. As Treisman concluded in his major study of budget transfers 'benefits are geographically targeted so as to appease the discontented rather than to reward the loyal' ${ }^{37}$ Thus Lavrov notes that: 'among the regions that supported the new Constitution in the December 12, 1993 referendum, 40 per cent made gains and 26 per cent lost out. But among the regions that rejected the Constitution, 55 per cent gained and only 18 per cent suffered losses'..$^{38}$

There is now also a substantial amount of economic data to support 
the hypothesis that the ethno-national subjects of the federation have been favoured over the territorial subjects in tax concessions and federal aid. As Smith notes: 'It is the geopolitical leverage and rhetoric of nationalist politics - the threat or perceived threat of secession or withdrawal from the system of fiscal federalism - that result in the greater likelihood of a region's securing economic benefits'..$^{39}$

As Kahn observes, over the period 1992-94, 'more than seventy presidential decrees and resolutions gave special federal dispensations and exemptions to fourteen republics in the form of export quotas, licences and special resource rights'. ${ }^{40}$ And it was the ethnic republics which gained the most privileges from the bilateral treaties which they signed with Moscow. In 1992 one trillion roubles was allocated to the regions from the federal budget. However, an examination of those fifteen regions that received more from the federal budget than they contributed to it, showed that almost all of them (except Kamchatka) were republics or autonomous entities. As Leonid Smirnyagin observed, 'a conclusion suggests itself: the political advantages that the republics have in comparison with the provinces have ensured them economic advantages as well' ${ }^{41}$ And table 5.10 clearly shows that the ethnic republics and ethnic autonomies in 1996 had higher levels of expenditure per capita, retained a higher percentage of their tax revenues, and a greater portion of their income was allocated to them from federal sources. ${ }^{42}$

Table 5.10 Variations in the financial status of subjects of the Russian Federation with different constitutional status, 1996

\begin{tabular}{lccc}
\hline & $\begin{array}{c}\text { Budget expenditure } \\
\text { per capita in } \\
\text { thousand roubles) }\end{array}$ & $\begin{array}{c}\text { Share of federal } \\
\text { aid in the budget } \\
\text { as expense (\%) }\end{array}$ & $\begin{array}{c}\text { Share of federal taxes } \\
\text { credited to the } \\
\text { subject's budget (\%) }\end{array}$ \\
\hline $\begin{array}{c}\text { Average for subjects } \\
\text { of the Russian }\end{array}$ & 1,536 & 11.7 & 56.8 \\
$\quad \begin{array}{l}\text { Federation } \\
\text { Republics }\end{array}$ & 1,750 & 17.9 & 70.1 \\
$\begin{array}{l}\text { Krais and oblasts } \\
\text { Federal cities }\end{array}$ & 1,242 & 12.7 & 61.0 \\
$\begin{array}{l}\text { Autonomous } \\
\text { okrugs, oblasts }\end{array}$ & 2,635 & 3.9 & 44.0 \\
Including 'poor & 6,525 & 5.9 & 50.0 \\
autonomies' & 2,878 & 42.3 & 74.2 \\
\hline
\end{tabular}

Source: Aleksei M. Lavrov, 'Budgetary Federalism', in Jeremy R. Azrael and Emil A. Payin, Conflict and Consensus in Ethno-Political and Center-Periphery Relations in Russia (California: Rand, 1998), p. 27.

Note: ${ }^{\text {a }}$ This refers to data for the ethnic autonomies excluding the rich Khanty-Mansi and Yamalo-Nenets AOs. 
Thus, an examination of the data (in table 5.10) for the territorial krais and oblasts shows that expenditure per capita was 1,242 (thousand roubles), federal transfers 12.7 per cent, and the share of credited taxes 70.1 per cent; whereas, for the ethnic republics the figures were 1,750 thousand roubles, 17.9 per cent and 70.1 per cent; and for the poor autonomies 2,878 thousand roubles, 42.3 per cent, and 74.2 per cent, respectively.

Moreover, those ethnic republics that have been the most confederalist in their demands and which have been willing to go furthest in their claims of national sovereignty have received the most privileges from the federal government. As can be seen in table 5.11, over the period 1992-95 Tatarstan, Bashkortostan and Sakha (Yakutiya) practically stopped transferring payments from taxes to the centre. And as Lavrov notes, the total losses to the federal centre from these three republics over the first 10 months of 1996 was 3.5 trillion roubles or 2.3 per cent of the tax income of the federal budget. As Smirnyagin notes, 'In 1992 Tatarstan paid only 93 million roubles in taxes [but] the republic received 38 billion roubles from the federal treasury in the form of subventions, special dispensations and credits - more than went to a dozen central provinces with a total population several times that of Tatarstan'.$^{43}$ These provinces paid over half the taxes that were collected - almost 250 billion roubles, that is, 2,688 times more than Tatarstan. ${ }^{44}$ And over the period 1995-98 all three republics continued to be granted much higher tax credits than the Russian Federation average.

Moreover, an examination of the draft budget for 2000 reveals that Bashkortostan, Tatarstan and Sakha continued to enjoy special privileges even although their bilateral treaties had expired. ${ }^{45}$ For example, Tatarstan was allowed to keep all of the excise duties on the sale of spirits on its territory, whereas the norm is 50 per cent. In total, Tatarstan payed 22.4 per cent of the taxes collected in its territory to the federal budget, whereas

Table 5.11 The portion of taxes credited to the budgets of 'privileged republics' in 1992-98 as a \% of total taxes collected in each republic's territory

\begin{tabular}{lrrrrrrr}
\hline Republics & 1992 & 1993 & 1994 & 1995 & 1996 & 1997 & 1998 \\
\hline Tatarstan & 99.9 & 100.0 & 83.8 & 77.3 & 80.3 & 75.4 & 88.9 \\
Bashkortostan & 99.9 & 100.0 & 87.5 & 73.8 & 71.9 & 73.0 & 82.2 \\
Sakha & 98.8 & 99.8 & 100.0 & 99.5 & 70.8 & 71.7 & 77.9 \\
$\begin{array}{l}\text { Average for } \\
\text { subjects RF }\end{array}$ & 48.3 & 62.9 & 64.8 & 59.1 & 57.3 & 56.3 & 62.9 \\
\hline
\end{tabular}

Source: Data for 1992-96 from A. M. Lavrov, 'Asimmetriya Byudzhetnovo Ustroistva Rossii: Problemy i Resheniya' in Asimmetrichnost ... 1997', p. 104. Data for 1997-98 from A. M. Lavarov, Federal'nyi Byudzhet I Regiony: Opyt analiza finansovykh potokov (Moscow: Instityt Vostok Zapad, 1999), p. 64. 
the average contribution from Russian regions is 71.4 per cent. ${ }^{46}$ And it has been calculated that if the special budget agreement with Tatarstan is rescinded, the Republic will lose 17 per cent of its income. ${ }^{47}$

Such politically motivated policies have done little to alleviate the sharp inequalities to be found across the federation. Putting out one fire by showering troublesome regions with extra resources has only led to the outbreak of fires in other regions. Regional inequalities have in fact increased in recent years. Whereas in 1990 the ten least developed regions were 2.3 times behind the ten most developed regions in terms of per capita industrial and agricultural output, in 1996 the gap was 4.5 times. $^{48}$ And since the August 1998 financial crises we have continued to see an increase in the gap between the rich and poor regions. Such high levels of inter-regional inequalities fuel tensions and jealousies between regional elites and intensify regional competition over the distribution of scarce federal subsidies. As Smirnyagin observes, citizens in a federation should be able to enjoy relatively equal benefits regardless of their place of residence and thus: 'It cannot be considered acceptable when some regions differ from others several times over in terms of such important indicators of social development as per capita income, production downturn, unemployment, infant mortality, or per capita support from public funds ... citizen's rights are inevitably violated here'. ${ }^{49}$

However, there are signs that the special budgetary deals with the republics is finally coming to an end. President Putin has begun to recentralise the economic system. As we noted above, the balance between the federal budget and subnational budgets has now moved in the favour of the centre. Moreover, under pressure from federal authorities and the new presidential representatives ('Polpredy') from 2001 the republics have begun to transfer a far greater share of their taxes to the federal government. Thus, as Rabinowitch observes, 'in Bashkortostan, in the first quarter of 2001, the republic increased its transfers to the federal government 2.3 times in comparison with the first quarter of 2000 . Of the 9.9 billion roubles in revenue collected for budgets at all levels (federal, regional, local), Bashkortostan sent more than 5 billion - more than 50 per cent to the federal budget. In the past this figure was only 18-20 per cent' ${ }^{50}$

Putin's creation of seven new federal districts has also intensified the levels of socio-economic asymmetry in the federation (see table 5.12). Thus, as Slay notes, there are now two economically powerful districts the Central and Volga districts which together account for ' 60 per cent of Russia's retail trade, 55 per cent of new housing contructed, 40 per cent of industrial output, and 47 per cent of its population'. In stark contrast the Southern and Far East districts 'account for only 15 per cent of Russia's industrial output, 18 per cent of housing constructed, and 13 per cent of retail trade' ${ }^{51}$ We discuss Putin's radical assault on the Yeltsinite federal system in chapter 8 . 
Table 5.12 Economic status of the seven federal districts

\begin{tabular}{|c|c|c|c|c|c|c|c|c|}
\hline District & $\begin{array}{l}\text { No. of } \\
\text { subject } \\
\text { of RF }\end{array}$ & $\begin{array}{l}\text { Russian } \\
\text { population } \\
(\%)\end{array}$ & $\begin{array}{c}\text { Gross } \\
\text { regional } \\
\text { product } \\
(\%)\end{array}$ & $\begin{array}{l}\text { Volume of } \\
\text { industrial } \\
\text { production } \\
\quad(\%)\end{array}$ & $\begin{array}{l}\text { Volume of } \\
\text { agricultural } \\
\text { production } \\
\text { (\%) }\end{array}$ & $\begin{array}{c}\text { Capital } \\
\text { investment } \\
(\%)\end{array}$ & $\begin{array}{l}\text { Share of } \\
\text { exports } \\
(\%)\end{array}$ & $\begin{array}{c}R F \\
\text { budget } \\
(\%)\end{array}$ \\
\hline Central & 18 & 25 & 28 & 20 & 23 & 30 & 37 & 37 \\
\hline $\begin{array}{l}\text { North- } \\
\text { Western }\end{array}$ & 11 & 10 & 9 & 12 & 6 & 9 & 12 & 10 \\
\hline Southern & 13 & 15 & 8 & 6 & 16 & 8 & 4 & 6 \\
\hline Volga & 15 & 22 & 20 & 24 & 27 & 19 & 12 & 17 \\
\hline Ural & 6 & 9 & 15 & 19 & 8 & 17 & 18 & 15 \\
\hline Siberian & 16 & 14 & 14 & 14 & 17 & 11 & 13 & 11 \\
\hline Far Eastern & 10 & 5 & 6 & 6 & 4 & 5 & 4 & 4 \\
\hline Total & 89 & 100 & 100 & 100 & 100 & 100 & 100 & 100 \\
\hline
\end{tabular}

Source: Natal'ya Zubarevich, Nikolai Petrov and Aleksei Titkov - 'Federal'nye okruga - 2000' in Russia's Regions in 1999: An Annual Supplement to Russia's Political Almanac (Moscow: Carnegie Centre, 2000), p. 176.

\section{Notes}

1 P. Hanson and M. Bradshaw (eds), Regional Economic Change in Russia (Cheltenham: Edward Elgar, 2000), p. 22.

2 K. Zhuravaskaya, 'Inter-governmental relations in Russia', Russian Economic Trends, 8:1 (1999), 46.

3 P. Hanson, S. Artobolevskiy, O. Kouznetsova and D. Sutherland, 'Federal government responses to regional economic change', in Hanson and Bradshaw (eds), Regional Economic Change, p. 113.

4 A. M. Lavrov, J. Litwack and D. Sutherland, Fiscal Federalist Relations in Russia: A Case for Subnational Autonomy (OECD, 2001), p. 9.

5 Ibid.

6 According to Emil Pain the federal share is actually 63 per cent and the regions now receive 37 per cent. See, E. Pain, "Back to the USSR": new trends in Russian regional policy', Demokratizatsiya, 9:2 (Spring 2001), 186.

7 Ibid., p. 10.

8 Ibid.

9 E. Savchenko, Vedemosti (27 July 2000). As cited in EWI Russian Regional Report, 5:30 (August 2, 2000), 3.

10 Ibid.

11 Ibid., p. 13.

12 Economic Surveys: Russian Federation (OECD, 2000), p. 24.

13 A. G. Makushkin, Federal Budget and the Regions: A Case Study of Fiscal Flows (Moscow: Dialogue-MSU, 1999), p. 5.

14 Lavrov, et al., Fiscal Federalist, p. 14.

15 Economic Surveys, p. 25.

16 Hanson et al., 'Federal government responses', p. 106

17 See C. Ross, Local Government in the Soviet Union (New York: St Martin's Press, 1987). 
18 Lavrov et al., Fiscal Federalist, p. 14.

19 D. Lussier, EWI Russian Regional Report (January 2001), 23.

20 P. Hanson, 'Economic change and the Russian provinces', in J. Gibson and P. Hanson (eds), Transition from Below: Local Power and the Political Economy of Post-Communist Transitions (Cheltenham: Edward Elgar, 1996), p. 187.

21 E. Yasin, 'Regionalism: an evil or a boon?', Rossiya (December 16, 1992), 14, translated in CDPSP, 44: 52 (1992), 9-12.

22 L. Vardomskii, 'Vneshneekonomicheskie svyazi regionov', in Russia's Regions in 1999 (Moscow: Camegie Centre, 2000), p. 113.

23 O. V. Kuznetsova, 'Territorial'naya struktura nalogovovo potentsiala', in A. M. Lavrov (ed.), Federal'nyi Byudzhet i Regiony: Opyt Analiza Finansovykh Potokov (Moscow: Instityt Vostok Zapad, MAKS Press, 1999), pp. 64-5.

24 Hanson and Bradshaw, 'Regional dynamics of economic restructuring across Russia', in Hanson and Bradshaw, Regional Economic Change, p. 44.

25 PlanEcon, Washington, DC, as reported in Radio Free Europe/Radio Liberty, Russian Federation Report, (March 8, 2001), pp. 11-14.

26 Sotsial'noe Polozhenie i Uroven' Zhizn' Naseleniya Rossii 2000 (Moscow: Goskomstat Rossii, 2000), pp. 99-101.

27 L. V. Smirnyagin (ed.), Rossiiskie Regiony Nakanyne Vyborov - 95 (Moscow: Yuridicheskaya Literatura, 1995).

28 Thirty-one subjects if we include two regions with 49.4 per cent.

29 Sotsial'noe Polozhenie, pp. 199-201.

30 As is usual Chechnya is not included. See S. N. Smirnov, Regional'nye Aspekty Sotsial'noi Politiki (Moscow, GELIOS: 1999), pp. 63-4.

31 L. I. Sergeev, Gosudarstvennye i Territorial'nye Finansy (Kaliningrad: Yantarnyi skaz, 2000), pp. 141-2.

32 A. M. Lavrov, 'Why subsidised regions vote for Communists - or myth about Russian budgetary federalism', Rossiiskiye vesti, Special Supplement, 'Political Milieu' (April 10, 1996), p. 3. Translated in CDPSP, 48:13 (1996), p. 7.

33 Using a different set of criteria which defines 'donors' as simply those regions where the amount of tax collected and credited to the federal budget exceeded the amount of financial aid turned over to the them, Laverov and Makushkin note that there were as many as 50 donors in 1998. See, A. M. Lavrov and A. G. Makushkin, The Fiscal Structure of the Russian Federation: Financial Flows Between the Centre and the Regions (Armonk, New York, London, England: M. E. Sharpe, 2001), p. xxxii. See also, A. G. Makushkin, Federal'nyi Byudzhet $i$ Regiony (Moscow: Institut Vostok Zapad, Dialog-MGU, 1999).

343.7 times in Koryak AO; 2.1-2.8 times in Adygeya, Kabardino-Balkariya, Kamchatka and Magadan oblasts; Komi-Permyak and Koryak AOs; 1.4-1.8 times in Karachaevo-Cherkesiya, North Ossetiya, Buryatiya, Altai Krai, Amur and Chita oblasts, Agin-Buryatiya AO; 1.1 times in Marii El, Mordoviya, Ivanovo and Pskov Oblasts. O. Kuznetsova, 'Regional'nye byudgety', in Russia's Regions in 1999, p. 77.

35 A. Lavrov, 'Budgetary federalism', in J. R. Azrael and E. A. Payin (eds), Conflict and Consensus in Ethno-Political and Centre-Periphery Relations in Russia (Santa Monica, California: Rand, 1998), p. 41.

36 V. Tolz and I. Busygina, 'Regional governors and the Kremlin: the ongoing battle for power', Communist and Post-Communist Studies, 30:4 (1997), 423. 
37 D. Treisman, 'The politics of intergovernmental transfers in post-Soviet Russia', British Journal of Political Science, 26 (1996), p. 329.

38 A. M. Lavrov, 'Russian budget federalism: first steps, first results', Sevodnya (7 June 1995), p. 5. Translated in CDPSP, 47:23 (July 5, 1995), p. 3.

39 Smith, The Post-Soviet States, p. 197.

$40 \mathrm{Kahn}$, 'Federal façade', p. 203.

41 L. V. Smirnyagin, 'The distribution of subsidies to Russia's region's is unfair', Sevodnya (June 25, 1993), p. 2.

42 Lavrov, 'Budgetary federalism', p. 27.

43 Tambov, Ivanovo, Ryazan, Smolensk, Vladimir, Kursk, Belgorod, Yaroslavl, Orel, Bryansk, Kostroma and Kaluga Provinces.

44 Smirnyagin, 'The distribution of subsidies', p. 2.

45 Lavrov, et al., Fiscal Federalist, p. 8.

46 Kuznetsova, 'Regional'nye byudgety', in Russia's Regions in 1999, p. 80.

47 L. V. Smirnyagin, 'Federalizm po Putiny ili Putin po Federalizmu (zheleznoi pyatoi)', Carnegie Briefing Papers, 3:3 (March 2001), 4.

48 N. Kuzina, 'The federation is bursting at the seams', Rabochaya Tribuna (January 17, 1998), p. 1. Translated in Foreign Broadcast Information Service, SOV-98-019 (January 17, 1998), 2.

49 L. V. Smirnyagin, 'Power without a strict chain of command could be weakened unless action to strengthen and develop federalism is taken', Rossiiskiye vesti (January 16, 1998), 1-2. Foreign Broadcast Information Service, SOV-98-028, January 28, 2.

50 Igor Rabinovich, EWI Russian Regional Report, 6:17 (2001), pp. 6-8.

51 B. Slay, PlanEcon (September, 2000) p. 260. 